\title{
The value of tethering fishes (winter flounder and tautog) as a tool for assessing predation rates
}

\author{
Mary Carla Curran ${ }^{1, *}$, Kenneth W. Able ${ }^{2}$ \\ ${ }^{1}$ University of South Carolina Beaufort, 801 Carteret St., Beaufort, South Carolina 29902, USA \\ ${ }^{2}$ Marine Field Station, Institute of Marine and Coastal Sciences, Rutgers University, 800 Great Bay Blvd, \\ c/o 132 Great Bay Blvd, Tuckerton, New Jersey 08087-2004, USA
}

\begin{abstract}
We evaluated the effect of tethering 2 species of juvenile fishes on their behaviour and susceptibility to predation under laboratory conditions in order to determine whether these fishes can be effectively used in field studies designed to assess predation rates. More specifically, this laboratory study investigated: (1) the effect of tethering, which required puncturing the body, on 2 mobile fish prey: the winter flounder Pseudopleuronectes americanus (42 to $85 \mathrm{~mm}$ total length, TL), and the tautog Tautoga onitis (47 to $91 \mathrm{~mm} \mathrm{TL}$ ); and (2) whether the predators, the summer flounder Paralichthys dentatus and the blue crab Callinectes sapidus, preferentially preyed upon tethered individuals. The behaviour of tethered individuals varied between species. Tethered $P$. americanus buried more extensively (i.e. greater percentage of body covered by sand) than untethered individuals. Therefore, tethering this species may reduce predation by visual predators because individuals are less visible. Tethered $T$. onitis were more likely than untethered individuals to occupy open areas of the experimental pool rather than to be found near shelter. In this case, tethering may increase potential predatory attacks because tethered fish are more accessible. Despite differences in behaviour caused by tethering $P$. americanus, there was no significant difference between the rates of predation by $P$. dentatus on tethered versus untethered individuals. However, as predicted by the change in $T$. onitis behaviour, $P$. dentatus preyed more frequently on tethered individuals than untethered ones. $C$. sapidus, a predator that uses olfactory cues, preferentially selected tethered $P$. americanus. The preference for tethered individuals may depend in part upon the release of prey body fluids and subsequent detection by predators that use olfactory cues. Furthermore, tethered individuals may change their shelter-seeking behaviour, and thus confound potential habitat-specific differences in relative predation rates. As a result, tethering as a tool to determine predation rates should be used cautiously for fishes. At a minimum, laboratory observations to detect tethering artifacts should be conducted before field experiments.
\end{abstract}

KEY WORDS: Tethering $\cdot$ Predation $\cdot$ Prey behaviour $\cdot$ Prey susceptibility

\section{INTRODUCTION}

Tethering has been used on a wide variety of organisms, mainly invertebrates, in order to evaluate predation rates (Heck \& Thoman 1981, Heck \& Wilson 1987, Aronson 1989, Barshaw \& Able 1990, Wilson et al. 1990, Witman \& Sebens 1992, Barbeau \& Scheibling 1994). Often such studies address relative predation rates between habitats, but this can be confounded by

·E-mail: ibfrt34@vm.sc.edu having different numbers of predators at different sites (Witman \& Sebens 1992) or even different predator species. Recently, as part of a larger inquiry into artifacts associated with experimental manipulations, Peterson \& Black (1994) questioned the interpretation of tethering data. Although their comments have been challenged (Aronson \& Heck 1995), the concerns of Peterson \& Black (1994) regarding the artifacts of tethering might be particularly appropriate for fishes, which are harder to tether because of their greater mobility and lack of an exoskeleton for tether attachment. To date, we know little about these artifacts 
Table 1. Known papers on fish tethering, including the habitat used for each experiment, the objectives, and whether any artifacts of tethering were critically evaluated

\begin{tabular}{|c|c|c|c|}
\hline Source & Habitat & Objective & $\begin{array}{l}\text { Evaluation of } \\
\text { tethering artifacts }\end{array}$ \\
\hline Shulman (1985) & Coral reef & $\begin{array}{l}\text { To determine time to predation for Haemulon } \\
\text { flavolineatum with respect to distance from reef }\end{array}$ & None \\
\hline Mclvor \& Odum \{1988\} & $\begin{array}{l}\text { Temperate fresh- } \\
\text { water marsh creek }\end{array}$ & $\begin{array}{l}\text { To compare predation rates on Fundulus heteroclitus } \\
\text { in depositional vs erosional creek habitats }\end{array}$ & None \\
\hline Rozas \& Odum (1988) & $\begin{array}{l}\text { Temperate fresh- } \\
\text { water marsh creek }\end{array}$ & $\begin{array}{l}\text { To compare predation rates on Fundulus heteroclitus } \\
\text { between areas with different amounts of submerged } \\
\text { aquatic vegetation }\end{array}$ & None \\
\hline Ruiz et al. (1993) & Temperate estuary & $\begin{array}{l}\text { To compare predation rates on Fundulus heteroclitus } \\
\text { between deep and shallow areas }\end{array}$ & None \\
\hline
\end{tabular}

because of the small number of papers published on only a few species. Furthermore, 3 of the 4 papers included results from a hardy species, the killifish Fundulus heteroclitus, and none of them addressed the potential artifacts caused by tethering when considering habitat-specific predation rates (Table 1). Some artifacts, which may not be consistent across species or habitats, include: (1) providing usually unimportant predators a chance to consume restrained prey; and (2) altering prey behaviour as a result of tangling in highly structured habitat, struggling, or creating unnatural shelter-seeking behaviour.

The purpose of the present study is to evaluate the effect of tethering on the behaviour of 2 fish prey species to determine their susceptibility to predation in the laboratory. Our ultimate goal is to assess whether these species, and other fishes, can be used effectively in field tethering studies. We selected fish with 2 very different predator-avoidance strategies. One, the winter flounder Pseudopleuronectes americanus, is a flatfish that buries in the substrate. The other, the tautog Tautoga onitis, seeks shelter to avoid predation. Experiments were conducted to determine susceptibility of these species to a visual predator, the summer flounder Paralichthys dentatus (Olla et al. 1972), and a predator that uses olfactory cues, the blue crab Callinectes sapidus (Zimmer-Faust 1989, Weissburg \& ZimmerFaust 1994).

\section{MATERIALS AND METHODS}

All experimental animals were collected from Great Bay - Little Egg Harbor Estuary, an unpolluted area in southern New Jersey, USA (Psuty et al. 1993, Able et al. 1996). Callinectes sapidus were collected with traps, and fish were collected with seines, beam trawls, or traps. Some Paralichthys dentatus were collected using hook and line, but were observed in the laboratory to confirm that they fed normally. All predators and prey were maintained under ambient temperature, salinity, and photoperiod conditions in flowthrough seawater tanks prior to experiments. The predators ( $P$. dentatus and $C$. sapidus) were maintained on a diet of chopped frozen fish and live killifishes (Fundulus heteroclitus and Cyprinodon variegatus). The prey species were fed brine shrimp and chopped, frozen fish.

For each trial, individuals were placed in plastic pools ( $1 \mathrm{~m}$ diameter; $20 \mathrm{~cm}$ height) that were filled with $0.9 \mathrm{~cm}$ of sand (mean percent silt/clay of 0.71 ) and a static water depth of $10 \mathrm{~cm}$. All 10 pools were outdoors in a shaded area and thus exposed to natural photoperiod. The salinity remained near $32 \%$ throughout the experiments. Between trials, the pools were flushed with fresh seawater. All experiments were conducted between July and September 1994, when water temperatures were generally above $20^{\circ} \mathrm{C}$. For the trials using Paralichthys dentatus as the predator, the temperature ranged from 8 to $26^{\circ} \mathrm{C}$ (see Table 3 ). The experiments using Callinectes sapidus as the predator were conducted between June and August 1995, at temperatures ranging from 15 to $20^{\circ} \mathrm{C}$.

Prey behaviour. The effect of tethering on the burying behaviour of juvenile Pseudopleuronectes americanus ( $\mathrm{n}=60$ ) was determined in six $24 \mathrm{~h}$ trials (Table 2). These fish (42 to $85 \mathrm{~mm}$ TL) were young-ofthe-year individuals, based on Witting (1995). Fish were tethered through the dorsal musculature directly below the anterior portion of the dorsal fin. This area was chosen because it allowed for unrestricted movement of all fins. A hollow-bore needle (21 gauge) was pushed through the body, and monofilament line $4 \mathrm{~kg}$ test) was threaded through the needle, and then the needle was removed. One end of the tether line was melted into a thick knot that prevented it from passing 
through the fish, and the other end of the $0.5 \mathrm{~m}$ length line was attached to a weight that was placed in the center of the pool. This arrangement enabled the fish to move around the entire pool. For each of the trials, 5 individuals were randomly selected to be untethered and 5 were tethered; all fish were randomly assigned to 1 of the 10 pools. Fish were observed every $3 \mathrm{~h}$ and evaluated for the percent body covered by sediment (i.e. $0,25,50,75$, or $100 \%$ covered). The observation times coincided with distinct periods of the tidal cycle (i.e. high tide, $3 \mathrm{~h}$ after high tide, low tide, and $3 \mathrm{~h}$ after low tide) to evaluate the potential effect of residual tidal rhythms on burying behaviour. Night observations were made using a flashlight covered with a red filter to minimize disturbance to the fish.

The design for the juvenile Tautoga onitis ( $n=60$ ) experiment was similar to that described above, and individuals were tethered in the same manner for six $24 \mathrm{~h}$ trials. These fish (47 to $91 \mathrm{~mm} \mathrm{TL}$, Table 2) were also young-of-the-year individuals (Sogard et al. 1992). Their shelter-seeking behaviour, which is a typical response for this species (Olla et al. 1974, Olla \& Samet 1977), was assessed to determine the effect of tethering. A single oyster shell (ca $12 \mathrm{~cm}$ in length) was placed in each pool approximately $15 \mathrm{~cm}$ from the pool edge. For each observation period, $T$. onitis behaviour was characterized as one of the following shelter-seeking behaviours: resting against or within $1 \mathrm{~cm}$ of the side of the pool; resting in or by the oyster shell; or resting in the open sandy area of the pool. The first 2 categories were analyzed separately, and also combined to produce the shelter-seeking behaviour category. In all of the cases in which resting occurred, fish were immobile except for respiratory movement and minimal movement of their pectoral fins. In a few cases the fish were swimming and therefore not included in the analysis.

Prey susceptibility. Paralichthys dentatus was chosen as one of the predators because it is a visual preda-

Table 2. Summary of sample sizes, and predator and prey lengths for both the prey behaviour and prey susceptibility experiments. TL: total length of fish; CW: carapace width of Callinectes sapidus

\begin{tabular}{|lccc|}
\hline Experiment & $\begin{array}{c}\text { No. of } \\
\text { trials }\end{array}$ & $\begin{array}{c}\text { No. of } \\
\text { individuals }\end{array}$ & $\begin{array}{c}\text { Size range (mm } \\
\text { TL or mm CW) }\end{array}$ \\
\hline Prey behaviour: & & & \\
$\quad$ Pseudopleuronectes americanus & 6 & 60 & $42-85$ \\
Tautoga onitis & 6 & 60 & $47-91$ \\
Prey susceptibility: & & & \\
$\quad$ Paralichthys dentatus as predator & & 70 & $138-435$ \\
$\quad$ Pseudopleuronectes americanus & 11 & 216 & $37-112$ \\
$\quad$ Tautoga onitis & 8 & 154 & $25-111$ \\
Callinectes sapidus as predator & & 30 & $79-139$ \\
$\quad$ Pseudopleuronectes americanus & 3 & 60 & $37-85$ \\
\hline
\end{tabular}

tor (Olla et al. 1972), is piscivorous (Burke 1995), and is known to feed on Pseudopleuronectes americanus (Poole 1964, Festa 1979). We thought it an appropriate species for the experimental pools because it is often found in confined areas such as intertidal creeks (Szedlmayer \& Able 1992) and on the vegetated marsh surface (Hettler 1989). Before conducting the tethering experiments, an initial study was performed to determine the appropriate size range of $P$. americanus that could be ingested by $P$. dentatus (96 to $450 \mathrm{~mm} \mathrm{TL}$ ). These predators ate $P$. americanus that were up to $48 \%$ of their body length, and consistently ate fish 30 to $40 \%$ of their length. Therefore, for the tethering experiments, the mean size of $P$. americanus was $24 \%$ (range 17.9 to $50.9 \%$ ) of the predator length. The mean Tautoga onitis size was $22 \%$ of the summer flounder size (range 17.3 to $31.5 \%$ ).

To test whether Paralichthys dentatus preferentially preyed on tethered or untethered individuals, trials were conducted using both prey species. For each species, a pair of 2 similarly sized prey were chosen, and 1 was randomly selected to be tethered. For Pseudopleuronectes americanus, the average length difference between individuals within a pair was $1.4 \%$, and for Tautoga onitis, the average difference was $3 \%$. After the 2 prey individuals were placed in each pool and given $10 \mathrm{~min}$ to acclimate, 1 predator, which was starved for $24 \mathrm{~h}$, was introduced and the first eaten prey (tethered or untethered) was recorded. During October to November 1994, observations were made approximately every $3 \mathrm{~h}$ to coincide with precise phases of the tidal cycle. It was determined that the period between observations was too long, and in 1995 observations were made every $1.5 \mathrm{~h}$. A total of 11 trials were completed using $P$. americanus as prey between October and November 1994, and between June and July 1995 (Table 2). Eight trials were completed using $T$. onitis during the same period in 1994, and between August and September 1995 (Table 2). All trials were terminated after $48 \mathrm{~h}$ regardless of whether a prey item was eaten.

Callinectes sapidus was selected as the other predator because it uses olfactory cues (Zimmer-Faust 1989, Weissburg \& Zimmer-Faust 1994), and because a preliminary field study demonstrated that tethered Pseudopleuronectes americanus were preyed upon by $C$. sapidus (unpubl. data). The experiments using $C$. sapidus were similar to those using Paralichthys dentatus except that only 3 trials were conducted and $P$. americanus was the only prey species used (Table 2). The prey total lengths were 

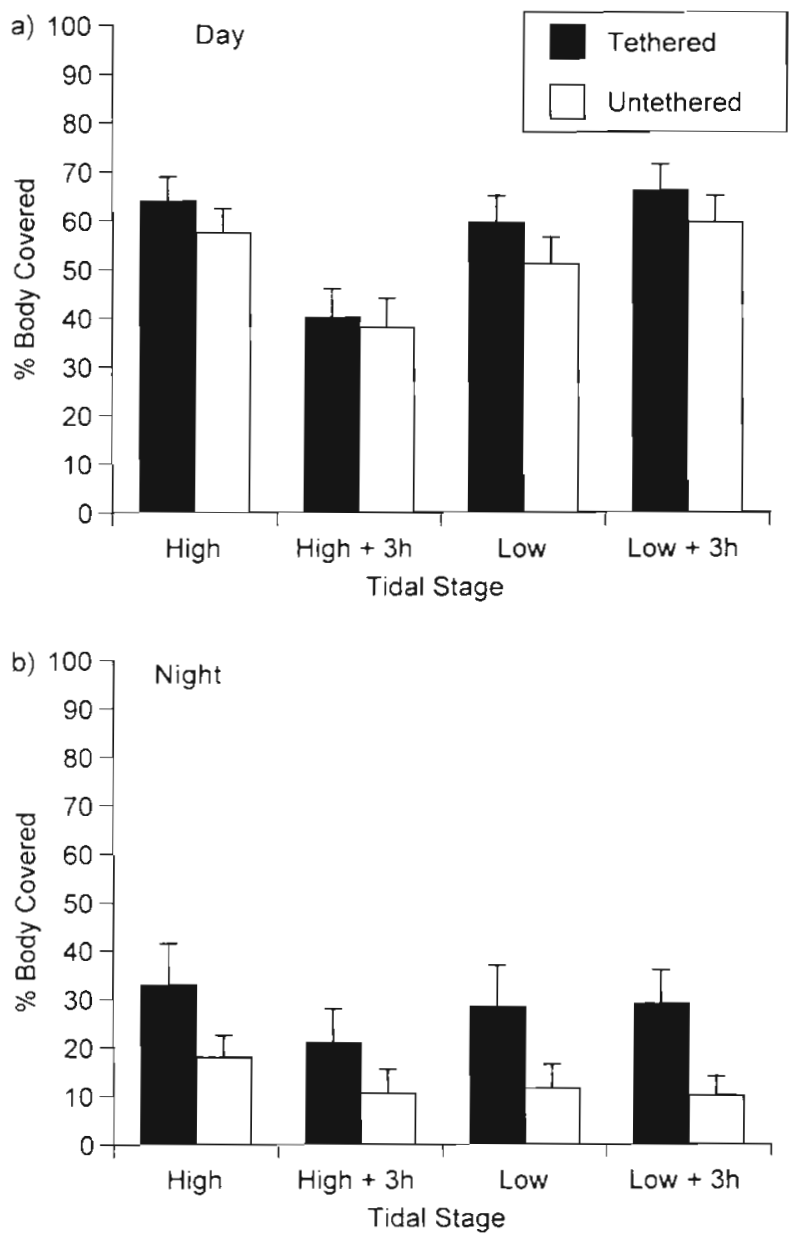

Fig. 1 Pseudopleuronectes americanus. Burial response for tethered and untethered winter flounder during the (a) day and (b) night through 4 tidal stages. Error bars are $+1 \mathrm{SE}$

between 40 and $60 \%$ of the carapace width of the crab ( 79 to $139 \mathrm{~mm}$ ). Individuals within each pair of prey did not differ in total length from each other by more than $4.8 \%$. These trials were conducted between June and August 1995.

Analysis. Analysis of prey behaviour was performed using the categorical modeling (CATMOD) technique designed by the Statistical Analysis Systems (SAS Institute 1988). This procedure was appropriate because repeated measurements were taken for each individual. The technique enabled us to determine whether burial (the discrete response variable) was independent of time of day, tidal stage, or tethering. The Tautoga onitis data were analyzed similarly to determine whether the response variable, i.e. the percentage of the number of observations for which individuals sought shelter (side of pool and/or shell), was independent of the time of day, tidal stage, or tethering. For the predation study, the CATMOD procedure determined whether fish consumption (the discrete response variable) was independent of temperature or treatment type (tethered or untethered). For both studies, a variable was considered significant if $p<0.05$.

\section{RESULTS}

\section{Prey behaviour}

Tethering affected the behaviour of both prey. Burying behaviour differed between tethered and untethered Pseudopleuronectes americanus; tethered individuals had significantly more of their body covered by sand (Fig. 1). Time of day and tidal stage also influenced burying behaviour (Fig. 1). Both tethered and untethered animals were more exposed at night, and they were also more exposed $3 \mathrm{~h}$ after high tide. There was also a significant interaction between tide and time of day. For the CATMOD procedure, a nonsignificant residual $(\mathrm{p}=0.86)$ indicated that the model, which consisted of the variables time of day, tidal stage, treatment, and the described interaction, fits the data. Other behaviour, such as swimming was noted only once in the 270 observations, and that was for an untethered animal; struggling by tethered fish was not observed.

For Tautoga onitis, tethering significantly decreased shelter-seeking behaviour (Fig. 2). Tethered $T$. onitis were associated with cover [side of pool $(p=0.15)$ or the oyster shell $(p=0.07)$ ] for a significantly smaller proportion of the observations than untethered individuals. Time of day significantly affected shelter-

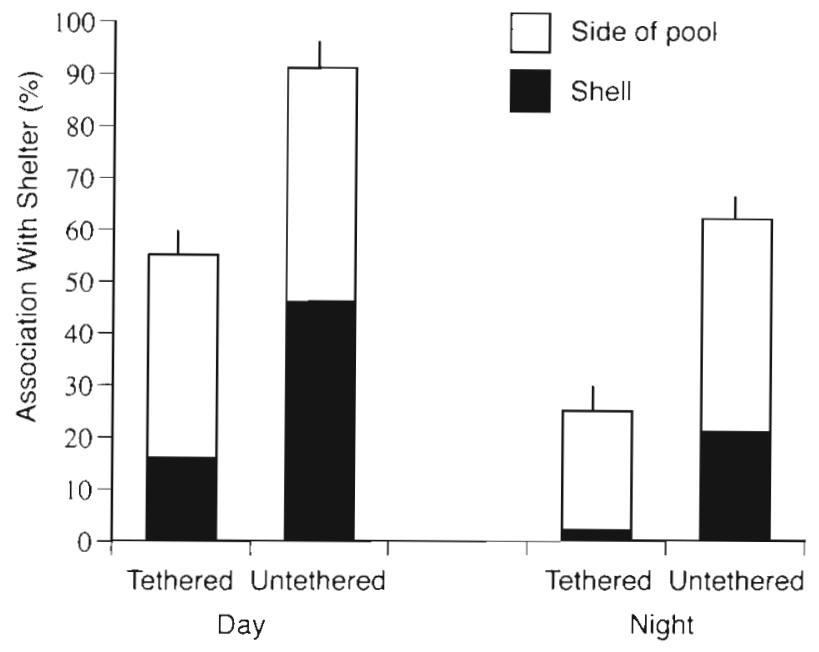

Fig. 2. Tautoga onitis. The percentage of the number of observations for which tethered and untethered tautog were observed to be associated with shelter (shell, side of pool) during the day and night. There was no significant effect of tidal stage. Error bars are $+1 \mathrm{SE}$ 
seeking behaviour; both treatment types were associated less with shelter at night when the 2 shelter-seeking behaviours were also combined. The CATMOD procedure also yielded a nonsignificant residual ( $p=0.79$ ) indicating that the above model, composed of time of day and treatment, fits the data. Instead of seeking shelter, fish were more likely to be in the open sandy area of the pool and their body orientation was unusual. They were not upright, but were slightly tilted to one side. In the 270 observations, swimming was seen only 8 times for tethered individuals, and 13 times for untethered ones. During our observation periods, tethered individuals were never seen to struggle against the tether.
Table 3. Results of the prey susceptibility study in which either $P_{s e u d o p l e u-}$ ronectes americanus or Tautoga onitis were exposed to predation by Paralichthys dentatus to determine whether tethered and untethered prey were preyed upon equally. As there were 10 experimental pools for each trial, the sum of the 2 treatment columns cannot exceed 10 . The mean temperature for each trial is also included

\begin{tabular}{|lcccccc|}
\hline Trial & $\begin{array}{c}\text { No. of P. americanus } \\
\text { preyed upon } \\
\text { Tethered Untethered }\end{array}$ & $\begin{array}{c}\text { Temp. } \\
\left({ }^{\circ} \mathrm{C}\right)\end{array}$ & $\begin{array}{c}\text { No. of } T \text { onitis } \\
\text { preyed upon } \\
\text { Tethered Untethered }\end{array}$ & $\begin{array}{c}\text { Temp. } \\
\left({ }^{\circ} \mathrm{C}\right)\end{array}$ \\
\hline 1 & 1 & 4 & 12 & 2 & 2 & 11 \\
2 & 4 & 2 & 13 & 5 & 2 & 13 \\
3 & 4 & 1 & 12 & 2 & 0 & 8 \\
4 & 1 & 2 & 12 & 5 & 3 & 23 \\
5 & 2 & 0 & 16 & 5 & 4 & 22 \\
6 & 2 & 1 & 20 & 3 & 4 & 24 \\
7 & 0 & 2 & 20 & 3 & 0 & 22 \\
8 & 5 & 2 & 18 & 1 & 0 & 16 \\
9 & 5 & 2 & 23 & - & - & \\
10 & 0 & 3 & 22 & - & - & \\
11 & 4 & 3 & 26 & - & - & \\
Total & 28 & 22 & & 26 & 15 & \\
\hline
\end{tabular}

\section{Prey susceptibility}

With Paralichthys dentatus as the predator, there was no statistically significant difference between the number of tethered and untethered Pseudopleuronectes americanus preyed upon (Table 3). For the CATMOD procedure a nonsignificant residual $(\mathrm{p}=$ 0.13 ) indicated that the model, which contained treatment type as a parameter, fits the data. Of the 50 fish preyed upon, 28 were tethered individuals and 22 were untethered. There was, however, a statistically significant difference between the number of tethered and untethered Tautoga onitis preyed upon. Of the 41 fish eaten, 26 were tethered and 15 were untethered (Table 3). For this experiment, temperature significantiy affected the number of successful predation events, indicating that at colder temperatures $P$. dentatus were less likely to feed. For the CATMOD procedure a nonsignificant residual $(p=0.44)$ indicated that the above model, including temperature and treatment, fits the data. For Callinectes sapidus, there was a significant difference between the number of tethered and untethered fish eaten (Table 4). There were 21 successful predation events; only 1 untethered individual was eaten.

\section{DISCUSSION}

\section{Prey behaviour}

The behaviour of both prey species changed as a result of tethering. For Pseudopleuronectes ameri-
Table 4. Results of the prey susceptibility study in which Pseudopleuronectes americanus were exposed to predation by Callinectes sapidus to determine whether tethered and untethered prey were preyed upon equally. As there were 10 experimental pools for each trial, the maximum number in any column cannot exceed 10 . The mean temperatures are also included

\begin{tabular}{|lccc|}
\hline Trial & $\begin{array}{c}\text { No. of } P \text {. americanus preyed upon } \\
\text { Tethered }\end{array}$ & $\begin{array}{c}\text { Temp. } \\
\left({ }^{\circ} \mathrm{C}\right)\end{array}$ \\
\hline 1 & 6 & 0 & 17 \\
2 & 8 & 0 & 20 \\
3 & 6 & 1 & 15 \\
Total & 20 & 1 & \\
\hline
\end{tabular}

canus, tethered fish had a somewhat greater proportion of their body covered with sand, and as a result, may have been more cryptic. In this case, tethering may cause an underestimation of the relative predation rate because burial, and thus possibly predator avoidance, may increase. In another flatfish study, burying was found to decrease the vulnerability of Paralichthys olivaceus to predation by the black sea bream Acanthopagrus schlegeli in the laboratory (Yasunaga \& Koshiishi 1980).

For Tautoga onitis, tethered individuals spent significantly less time associated with shelter than untethered individuals, thereby presumably increasing the possibility of predation. This change in behaviour has important implications for the interpretation of previous field studies because the determination of habitatspecific predation has been one of the primary goals of 
tethering studies. Shulman (1985) determined that more tethered fish were consumed closer to a reef than they were $20 \mathrm{~m}$ away, indicating that the shelter of algal and seagrass cover was crucial for the survival of juvenile fishes. Similarly, Heck \& Thoman (1981). Rozas \& Odum (1988), Minello (1993) and Haywood \& Pendrey (1996) found that increased vegetation cover had a negative effect on predation pressure. However in our study, tethered $T$. onitis did not use the available shelter as often, therefore comparing 2 habitat types with different amounts of shelter would provide little insight into accurate measures of relative predation risk for this species. In other words, in this case, artifacts caused by tethering may cause differences in habitat complexity to be meaningless, as discussed by Peterson \& Black (1994). Shortening the tether to confine prey to specific microhabitats may overcome this problem but may confound the experiment in other ways because of prey constraint.

As we found for these 2 fish species, tethering has also been noted to affect shelter-seeking behaviour in a decapod crustacean. Tethered early benthic phase lobsters Homarus americanus burrowed less than untethered lobsters in mud (Barshaw \& Able 1990). However, there was no such difference when the substrate was peat or cobble, thus highlighting the importance of habitat-specific characteristics. These findings have an obvious impact on potential predation, because an exposed, small lobster is probably more likely to be eaten.

Our study was unique in that the effect of tethering on the behaviour of fish prey species was assessed in the laboratory before any field experiments were completed and as a result we have some doubts about the efficacy of tethering to assess predation rates in the field, at least for these 2 species. Based on the speciesspecific changes in prey behaviour that occurred, we believe that laboratory experiments are necessary before any experiments under natural conditions are conducted.

\section{Prey susceptibility}

Despite the fact that tethering resulted in behavioural changes for both prey species, prey susceptibility was not always affected. Therefore we urge that both prey behaviour and predator feeding strategies be considered. For the visual predator Paralichthys dentatus, there was no difference in their preference for tethered or untethered Pseudopleuronectes americanus, but there was a preference for tethered Tautoga onitis, which did not use shelter as much as untethered individuals and would therefore be more visible. $P$. dentatus primarily uses visual cues (Olla et al. 1972), so the release of body fluids may not be as serious an artifact as it would be for Callinectes sapidus, which relies primarily on olfaction to detect prey (Zimmer-Faust 1989, Weissburg \& Zimmer-Faust 1994). Because of the overwhelming preference of $C$. sapidus for tethered winter flounder, and because of the results of our preliminary field tethering study that showed that tethered fish were eaten by $C$. sapidus within hours, we believe that tethering may introduce serious artifacts for fishes such as $P$. americanus, which rely on concealment to avoid predation. The only manner in which to avoid this artifact is to tether the prey without piercing the body, which is not possible for most fishes. An additional concern is that the accurate comparison of relative predation rates between habitats may be compromised because of the changes in prey behaviour; fishes such as $T$. onitis respond differently to shelter when tethered.

Simply put, this experimental approach, as many others, has the potential to introduce significant artifacts (Peterson \& Black 1994). Therefore, care must be taken in its application, especially before applying the results from one species or habitat to another. Although we agree with Aronson \& Heck (1995) that tethering might be an appropriate technique to use to obtain information regarding relative predation rates, particularly for invertebrates, we have serious concerns about the validity of tethering in cases where body fluids are leaked into the environment.

Acknowledgements. This research was supported by funding from the Rutgers University Institute of Marine and Coastal Sciences (IMCS). Research assistance was primarily provided by J. Raffloer, A. Terry, and also by D. S. Duncan and S. Montgomery. We thank D. Witting for statistical assistance. This publication is IMCS Contribution No. 98-06.

\section{LITERATURE CITED}

Able KW, Lathrop R, De Luca MP (1996) Background for research and monitoring in the Mullica River-Great Bay Estuary. Institute of Marine and Coastal Sciences (IMCS) Rutgers, The State University of New Jersey IMCS Tech Rep 96-07, New Brunswick, NJ

Aronson RB (1989) Brittlestar beds: low-predation anachronisms in the British Isles. Ecology 70:856-865

Aronson RB, Heck KL Jr (1995) Tethering experiments and hypothesis testing in ecology. Mar Ecol Prog Ser 121: $307-309$

Barbeau MA, Scheibling RE (1994) Procedural effects of prey tethering experiments: predation of juvenile scallops by crabs and sea stars. Mar Ecol Prog Ser 111:305-310

Barshaw DE, Able KW (1990) Tethering as a technique for assessing predation rates in different habitats: an evaluation using juvenile lobsters Homarus americanus. Fish Bull US 88:415-417

Burke JS (1995) Role of feeding and prey distribution of summer and southern flounder in selection of estuarine nursery habitats. J Fish Biol 47:355-366 
Festa PJ (1979) Analysis of the fish forage base in the Little Egg Harbor Estuary. New Jersey Department of Environmental Protection Division of Fish, Game and Shellfisheries Bureau of Fisheries, Nacote Creek Research Station, Tech Rep $24 \mathrm{M}$

Haywood MDE, Pendrey RC (1996) A new design for a submersible chronographic tethering device to record predation in different habitats. Mar Ecol Prog Ser 143 $307-312$

Heck KL Jr, Thoman TA (1981) Experiments on predator-prey interactions in vegetated aquatic habitats. J Exp Mar Biol Ecol 53:125-134

Heck KL Jr, Wilson KA (1987) Predation rates on decapod crustaceans in latitudinally separated seagrass communities: a study of spatial and temporal variation using tethering techniques. J Exp Mar Biol Ecol 107:87-100

Hettler WF Jr (1989) Nekton use of regularly-flooded saltmarsh cordgrass habitat in North Carolina, USA. Mar Ecol Prog Ser 56:111-118

McIvor CC, Odum WE (1988) Food, predation risk, and microhabitat selection in a marsh fish assemblage. Ecology 69 : $1341-1351$

Minello TJ (1993) Chronographic tethering: a technique for measuring prey survival time and testing predation pressure in aquatic habitats. Mar Ecol Prog Ser 101:99-104

Olla BL, Bejda AJ, Martin AD (1974) Daily activity, movements, feeding, and seasonal occurrence in the tautog Tautoga onitis. Fish Bull US 72:27-35

Olla BL, Samet C (1977) Courtship and spawning behavior of the tautog, Tautoga onitis (Pisces:Labridae), under laboratory conditions. Fish Bull US 75:585-599

Olla BL, Samet CE, Studholme AL (1972) Activity and feeding behavior of the summer flounder (Paralichthys dentatus) under controlled laboratory conditions. Fish Bull US 70: $1127-1136$

Peterson CH, Black R (1994) An experimentalist's challenge: when artifacts of intervention interact with treatments. Mar Ecol Prog Ser 111:289-297

Poole JC (1964) Feeding habits of the summer flounder in Great South Bay. NY Fish Game J 11:28-34

Psuty NP, De Luca MP, Lathrop R, Able KW, Whitney $S$, Grassle JF (1993) The Mullica River-Great Bay Estuarine Research Reserve: a unique opportunity for research,

Editorial responsibility: Kenneth Heck (Contributing Editor), Dauphin Island, Alabama, USA preservation and management. Proceedings of Coastal Zone '93, July 1993, New Orleans

Rozas LP, Odum WE (1988) Occupation of submerged aquatic vegetation by fishes: testing the roles of food and refuge. Oecologia 77:101-106

Ruiz GM, Hines AH, Posey MH (1993) Shallow water as a refuge habitat for fish and crustaceans in non-vegetated estuaries: an example from Chesapeake Bay. Mar Ecol Prog Ser 99:1-16

SAS Institute Inc (1988) SAS/STAT user's guide, release 6.03 edn. Statistical Analysis Systems Institute, Cary, NC

Shulman MJ (1985) Recruitment of coral reef fishes: effects of distribution of predators and shelter. Ecology 66: $1056-1066$

Sogard SM, Able KW, Fahay MP (1992) Early life history of the tautog Tautoga onitis in the Mid-Atlantic Bight. Fish Bull US 90:529-539

Szedlmayer ST, Able KW (1992) Growth and temperatureinduced mortality of young-of-the-year summer flounder (Paralichthys dentatus) in southern New Jersey. Copeia 1992:120-128

Weissburg MJ, Zimmer-Faust RK (1994) Odor plumes and how blue crabs use them in finding prey. J Exp Mar Biol Ecol 197:349-375

Wilson KA, Able KW, Heck KL Jr (1990) Predation rates on juvenile blue crabs in estuarine nursery habitats: evidence for the importance of macroalgae (Ulva lactuca). Mar Ecol Prog Ser 58:243-251

Witman JD, Sebens KP (1992) Regional variation in fish predation intensity: a historical perspective in the Gulf of Maine. Oecologia 90:305-315

Witting DA (1995) Settlement of winter flounder, Pleuronectes americanus, in a southern New Jersey estuary: spatial and temporal dynamics and the effect of decapod predation. PhD dissertation, Rutgers University, New Brunswick, NJ

Yasunaga Y, Koshiishi Y (1980) Basic studies of problems on the propagation of plaice, Paralichthys olivaceus. I. Acclimatization to low salinity, feeding and gathering behaviour. Bull Jap Sea Reg Fish Res Lab 31:17-31

Zimmer-Faust RK (1989) The relationship between chemoreception and foraging behavior in crustaceans. Limnol Oceanogr 34:1367-1374

Submitted: October 24, 1996; Accepted: December 17, 1997 Proofs received from author(s): February 10, 1998 